\title{
The Impact of Itinerant Scholars on the Propagation of Islām in Ibadan, Nigeria
}

\author{
Lateef O. Abbas \\ University of Ibadan, Ibadan, Nigeria
}

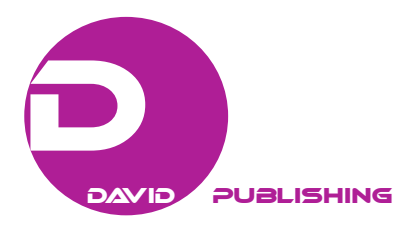

0 


\section{The Advent of Islām in Ibadan}

The exact date of the entry of Islām to Ibadan cannot be ascertained, but historical records reveal that it was at the early period of its foundation. According to some reports, there were Muslims in Ibadan as early as 1829 with a man called Igun Olohun or Gunugun in some of their records as their Imām.

By this time, Ibadan has taken shape as a cosmopolitan and garrison city. However, Islamic practice then was a private affair as this was attributed to the widespread circumstances of war, molestation by the pagans and suspicion that the Muslims were of the same faith with the Sokoto Jihädist who connived with Afonja to sack Oyo-Ile, the capital of Oyo empire.

\section{Efforts of the Itinerant Scholars at the Early Period of Islām in Ibadan}

Ibadan started to witness tremendous development during the time of Basorun Oluyole who reigned as Basorun of Ibadan between 1836 and 1850. At this time, many itinerant Mallams from Hausaland through Ilorin entered the city of Ibadan. Notable among them was Uthman bn Abubakar Baasunu (Baba Saannu) a native of Katsina who became a personal friend of Basorun Oluyole due to his spiritual power in which Oluyole found fulfillment.

It was also on record that before the arrival of Baasunu, Shaykh Ahmad Qifu from Bornu had arrived Ibadan during the time of Oluyedun, the Baale of Ibadan between 1830 and 1835. Ahmad Qifu settled at a place called Isale-Alfa where he first constructed a bamboo mosque. The first Central Mosque was constructed at Oja'ba area in 1830. Uthman bn Abubakar Baasunu was the chief Imām between 1839 and 1871 to be followed by Shaykh Ahmad Qifu who reigned between 1871 and 1872.

Other migrant scholars who came later either searching for greener pasture or people to convert (to Islām) found hospitable place in Ibadan. The spiritual power as well as literary experiences of these Mallams formed their jobs as spiritual advisers and Qur'ānic teachers of the children of Ibadan warlords and royal fathers. It is obvious that nearly all the warlords wanted their children to learn the Qur'ān and advanced Islamic studies to enable them be acquainted with the "secret" of the Mallams' charms and tira.

Many of the warlords and royal fathers of Ibadan patronised the scholars and subsequently embraced Islām. Among them were Osundina, the Osi Balogun and father of Basorun Uthman Apampa, who happened to be the first high ranking Ibadan warlord to embrace Islām. Basorun Ogunmola adopted Muhammad as his Muslim name to show his commitment to the new religion. Basorun Gaa who had a Muslim spiritual mentor from Iwo; Aare Latoosa had Shaykh Bello as his spiritual mentor; while Balogun Akere had Alfa Ishaq as his spiritual adviser. These Muslim clerics rendered prayers for spiritual fortification especially during wars.

It was also very significant in the growth of Islam in Ibadan that many Muslim clerics were enlisted in Ibadan army and even participated in wars. Bello, as quoted by Abdul-Rahmon, reports that the position of the chief Imām of Ibadan became vacant at a time while scholars next in rank, Sulayman Alagufon and Sanusi were actively involved in the Kiriji war. The former was turbaned on the war front while an acting chief Imām held the fort at home.

With the closeness of the early Muslims to the influential people, the foundation was laid for what was to be the propelling force for the spread of Islām. The first decade of the 20th century witnessed the influx of

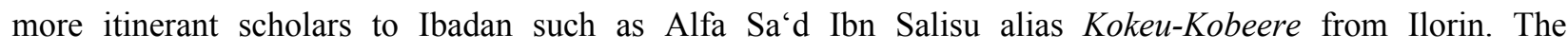
proselytisation activities of itinerant Shuy $\bar{u} k$ from Ilorin at this time helped a great deal in gaining a large 
number of adherents in Ibadan. Since that time, the religion of Islam has continued to gain momentum in the city of Ibadan and its environs.

\section{Da'wah Methods Exhibited by the Scholars of Islām}

$D a^{*}$ wah (Islamic propagation) which can be translated as call to the path of Allah, formed the most important part of the duties of Islamic scholars in Yorubaland. There were two types of $d a^{6} w a h$ as understood and carried out by the scholars. They are, propagation of Islām through education and through open public da'wah.

\section{Islamic Propagation Through Education}

One of the systems adopted by the scholars of Ibadan in the spread of Islām was education. They believed that knowledge of Islam is a necessary instrument for the understanding and spread of the religion. They therefore began to establish Qur'ānic schools which later graduated to Madāris and Marākiz.

The first formal school to be established at the early stage of Islām was that of Shaykh Abubakar bn Al-Qāsim Alaga. He was an Ilorin based Islamic scholar but an indigene of Ibadan whose father had settled in Ilorin over a period of time. When the Muslim community of Ibadanland heard that he was very versed in all branches of Arabic and Islamic education they sent for him to come and benefit his people with his bulk of knowledge. On arrival, he settled at Oke-Aremo where he established a school where he taught Nahw (Arabic grammar), Fiqh (Theology), Sarf (Etymology), Baläghah (Rhetorics), Hisāb (Mathematics), Hadìth (Prophetic traditions) and so on.

The school produced notable scholars like Hassan Bukhari Abata, Shaykh Malik Hussein, Shaykh Abubakar Onaado, his son Aminullahi Abubakar, Imām Sulayman Alagufon, Imām Abdullahi Baasunu, Shaykh AbdulSalam Ghatta, his brother Abubakar Ghatta, Imām Harun Motanmi and many others.

After the death of Shaykh Abubakar bn Al-Qasim Alaga in 1884, Shaykh Harun Motanmi took over as the head of the school and he became the teacher of Ibadan scholars ('Ulama'u). Among his products were Shaykh Muhammad Bello Usman, Shaykh Muhammad Katibi of Gege, Shaykh Saliu Abdulqadir, Shaykh AbdulSalam of Gege and Shaykh Tahir Malik Motala to mention but few.

The students of Shaykh Harun Motanmi also maintained Arabic and Islamic centres in the entire of Ibadanland. These centres formed the pioneering centres of Arabic and Islamic education in Ibadanland. It accommodated a number of students from the South-Western Nigeria. Ibadan thus became a worthwhile learning centre. Apart from Ilorin, Ibadan was more of Islamic academic centre than any other town in Yorubaland. Some graduates of these schools were made to teach in the newly established ones, some took to $d a^{6}$ wah work while a few lucky ones got admitted into universities in some Arab countries.

\section{Open Public Lecture as a System of Da'wah}

The open public lecture signifies the second $d a^{6}$ wah method displayed by the itinerant scholars in Ibadanland to disseminate knowledge of Islam. Historically, farming and trading majorly dominated the economy of Ibadan people in the 19th century. Within 20 years or so of the founding of the modern Ibadan, villages and hamlets had sprang up in large numbers. This made Ibadan people be double dwellers-living in both city and in the village.

Thus, every indigene of Ibadan had home in both the city and the village (Ibadan tile toko). This situation as a matter of fact necessitated the itinerant Mallams taking $d a^{6} w a h$ activities to people wherever they resided. 
Thus, the itinerant scholars would move from towns to towns, villages to villages for weeks and months educating people about Islam.

The practice of itinerary preaching entails that wherever an itinerant scholar was to preach, he would be followed by his students, disciples and even some of his admirers. At the town or the village scheduled to stage the open air service ( $w a z$ ), the first person to contact was always the Imam, who in most cases, played host to them as long as they remained in that vicinity. If the town or the village is without an Imām, then, the Baale (village head) would be contacted for permission. If they were permitted, they would proceed on the programme, but if not, they would move to another environment.

Most of the time, students of the scholars would herald their arrival by moving and singing round the town or the village to alert people of the $w a z$ that was imminent. Every scholar was with his own peculiar song. Among the most common to many scholars was:

Toniletalejo e jade wa, Alufawa fee se waasi

Enibawa debe a rere je, enibawa de be koniiwona.

Meaning:

The residents and the guest are implored to come out our teacher is here to preach.

Anyone that attends it (with us) will be rewarded and will be protected from hellfire.

It was gathered that some Islamic scholars in Ibadan got nicknamed in relation to waka (Yoruba poem) which they used to chant before the commencement of $w^{\prime}{ }^{\prime} z$ or at interlude. For instance, Shaykh $\mathrm{Sa}^{\text {' }} \mathrm{d} \mathrm{Ibn}$ Salisu a.k.a. Kokeu-Kobeere got the alias from his waka which reads thus:

Bawoni o se la o? Bawoni o se la o? Kokeu, kobeere, bawoni o se la o?

Meaning:

How will he be saved? How will he be saved? He who is not learned in Islam and does not inquire (about his religion), how will he be saved?

So also ShaykhAbdulganiyAgbotomokekere was so nicknamed with his popular waka that goes thus:

Agbotomokekere to $n$ fi tuba degbao,

Agbalagba to $\mathrm{n}$ se bee niko waa witi e.

Meaning:

It is understandable of a child who defers repentance, but an elderly person who does that is required to give his excuse.

The common practice was that the open public lecture took place in the night shortly after the night prayer (Salatul-Ishai) till the mid-night or sometimes early the following morning. There used to be interlude in the middle of the service and series of waka would be rendered by the Mallam and his students which made the programme very interesting and captivating.

Other features that added to the glamour of the lecture include the use of Arowaasi (Broadcaster) and Ajanaasi (the reciter of the Arabic texts of the Qur'ān) by the scholars. Arowaasi was vested with the duty of broadcasting the messages and the utterances of the scholar to the teeming congregation while Ajanaasi was saddled with the responsibility of reciting the verses of the Qur'ān with melodious and thrilling voices which the scholar would translate to Yoruba. This aspect made the audience so sensibly carried along with rapt attention that they would tend to ignore pain and boredom which the long sitting or standing might cause them. 
The sermon rendered through this open public da'wah was always made up of lectures on the pillars of Islam, which are fundamentals of the faith, especially the tawhid (oneness of God) aspect of the pillars. Other areas include good neighbourliness, duties of husband and wife and even duties of parents to their children and vice versa.

Some preachers also adopted a comparative system by making reference to both the Glorious Qur'ān and the Holy Bible. Among them were Shaykh Najimudeen Akindele, Alhaj Shaykh Ajadi Akeukewe and a host of others. Olanrewaju had this to say to the credit of Shaykh Najimudeen Akindele:

The unique method of preaching adopted by Shaykh Najimudeen made him to excel other preachers in Ibadan. The use of waka (Yoruba poem), several quotations from the Holy-Bible and narration of relevant stories in support of his Qur'ānic references attracted many young and old ones to his preaching.

As part of the programme, members of the congregation were always given the opportunity to ask questions that were agitating their minds and the Mallams would take time to answer them. It was also very common that the preacher always concluded the programme with supplications. At the prayer session, the audience resorted to giving the scholar some sadaqah (voluntary donation) that ranges from money to food items and even clothing materials. Many scholars relied on these donations as their source of income and were satisfied with it.

Many itinerant scholars documented their preaching adventures while it was documented on behalf of some others. For example, Shaykh Bolaji Akeukewe puts the following down in his book titled Asiri Anabi Muhammad (the secret of Prophet Muhammad) in Yoruba language.

Mo se waasi kaakiri Ibadan ati gbogbo ile Yoruba ki n to bosi Eko ni odun 1947.

Meaning:

I made preaching trips round Ibadan and Yorubaland before I moved to Lagos in 1947.

Also in the book, he made a list of 179 towns and villages in Nigeria and abroad where he organised open public lectures and the number of times he preached in all of them. In Ibadan and environs, 16 towns and villages were extracted from the list. They are:

\begin{tabular}{lll}
\hline S/N & Names of towns & Times of $\mathrm{Wa}^{\mathrm{s}} \mathrm{I}$ \\
\hline 1 & Aba Alfa & 2 \\
2 & Ejioku & 12 \\
3 & Ijaye & 43 \\
4 & Ajeja & 2 \\
5 & Moniya & 6 \\
6 & Idi-Ose & 4 \\
7 & Erunmu & 24 \\
8 & Oyedeji & 18 \\
9 & Iware & 25 \\
10 & Ile-Igbon & 13 \\
11 & Onidundu & 28 \\
12 & Ofa-Oko & 17 \\
13 & Lalupon & 31 \\
14 & Lagun & 16 \\
15 & Akanran & 10 \\
16 & Ibadan Metropolis & 665 \\
\hline
\end{tabular}


Also, Olanrewaju in his work, "Shaykh Najimudeen Akindele: A portrait of an Islamic scholar", explains the missionary work of Shaykh Najimudeen as an itinerant scholar in Lagos, Oyo, Osun, Ogun and Ondo states of Nigeria and abroad. The work was detailed on all cities, towns and villages where the Shaykh staged open public lectures which included the city of Ibadan and environs, the area of focus of this paper. The above represents the practice of itinerary preaching in the early periods of Islam in Ibadan.

\section{Some Notable Itinerant Preachers in Ibadanland}

It is noteworthy that Ibadan has a large record of itinerant preachers among the Yoruba extraction. The city grew up to become a rendezvous for itinerant scholars who were either migrants from Northern part of the country or other parts of Yorubaland as well as the indigenes of Ibadan. Abdul-Raheem corroborated these statements when he states thus:

It is instructive to mention here that the Arabic works that came out of Ibadan could not be wholly ascribed to it. The authors came from various parts of Yorubaland on a migratory waves that has turned Ibadan to a sort of market of literary waves...

Among the itinerant scholars who featured prominently in Ibadan and environs between the early 19th century and middle of the 20th century included among others-Imām Abdullah Igun Olohun (the first chief Imām of Ibadan), Shaykh Uthman bn Abubakar Baasunu from Katsina (the second chief Imām of Ibadan), Shaykh Ahmad Qifu from Bornu (the third chief Imām of Ibadan), Shaykh Abubakar Ibn Salihu al-Kariz, Shaykh Abubakar bn Qasim Alaga, Shaykh Harun Motanmi from Osogbo, Shaykh Harun Agbeni (the fourth chief Imām of Ibadan), Shaykh Sulayman Alagufon, a native of Bida (the fifth chief Imām of Ibadan), Shaykh Ibrahim Gambari, a native of Zaria (the sixth chief Imām of Ibadan), Shaykh Mahmud Toto, Shaykh Muhammad Sanusi Alawiye, Alfa Sa'd Ibn Salisu a.k.a. Kokeu-kobeere, Alfa Hassan Abata (all from Ilorin), Alfa Katibi Sanusi from Ofa-Ile and Alfa Malik bn Husayn from Ikoyi-Ile. Others were Alhaj Shaykh Abdulganiy Agbotomokekere, Shaykh Najimudeen Akindele, Shaykh B.S. Bolaji (Akeukewe Agba), Shaykh Bunyamin Adisa Motala, Imām Sabiq Oloso of Lagun and Shaykh Muhammadul-Awwal generally known and addressed as Baba-ni-Aba-Alfa. Shaykh Awwal was instrumental to series of progress recorded by Muslims of Ariku and Aba Alfa in the Lagelu local government of Oyo state.

There are other eminent scholars who featured in the city of Ibadan and environs during the period on occasional basis. They could be best described as visiting itinerant scholars. Prominent among them were Shaykh Kamalideen Al-Adabiy from Ilorin, Shaykh Adam Abdullah Al-Ilory, who, according to a written record, had Lagun (a town in the eastern part of Ibadan) as one of the first places where he engaged in enlightenment on Islām. He was in Lagun in the late 1930s and after a few years of successful da 'wah, he left Lagun to continue his Islamic propagation elsewhere.

Other scholars in the category included Alhaj Yahya Abimojesin of Pakata area, Ilorin, Shaykh Abdulbaaki Muhammad from Ajijagunesin compound, Iwo, Osun state, who on the first of every January, for scores of years, staged open public lectures in front of the ancient Mapo hall in the heart of the city of Ibadan and Shaykh Usamah of Kuta near Iwo, Osun state who, for many years, paid intermittent visits to Ibadan on preaching mission. His missionary sojourn took him round nearly all the areas in Ibadan and whenever he was in the city, he would lodge at Aliwo compound, Aliwo area, Ibadan. 
In the post-independence era of Nigeria, many personalities distinguished themselves as itinerant scholars in Ibadan. They include Alhaji Tiamiyu Busari of Popoyemoja, Alhaj Salahuddin Maye Akeukewe of Isale-Alfa area, Alhaj Abdul-Wahab Adediran Oluwakemi of Oja 'ba area, Alhaj Ajadi Akeukewe, Shaykh Keke of Beyerunka area, Shaykh Raji Egbekunle (Asisoloriro) of Lalupon, Shaykh Muhyideen Ajani Bello, Shaykh Liadi Ajisafe Akilapa, Shaykh AbdulAzeez Ajagbemokeferi and Alhaj Moshood Olanrewaju Adepoju.

\section{Effects of Itinerary Preaching on Ibadan Muslims}

No doubt, the itinerary scholars had impacted Islām immensely in Ibadanland. First, the efforts of the itinerant scholars led to the conversion of many royal fathers and warlords of Ibadan to Islam. People like Osundina, the Osi Balogun of Ibadan and father of Basorun Uthman Apampa, who happened to be the first high ranking Ibadan warlord to embrace Islam, Basorun Ogunmola who adopted Muhammad as his Muslim name, Basorun Gaa, Aare Latoosa and Balogun Akere to mention but few.

The conducive atmosphere the itinerant scholars enjoyed in Ibadanland and the proximity of some of them to who-is-who in the community made it possible for them to take $d a$ 'wah outing to every nook and cranny of the city and its environs with which they were able to convert as many non-Muslims as possible to Islam. Series of methods were applied by scholars to achieve their objectives.

It was on record that Shaykh Najimudeen Akindele's methods of preaching were very interesting to the young ones. In fact, he remained the first preacher with large audience and thousands of people had become Muslims through his preaching activities. As a gifted preacher, Najimudeen never preached Islam in any town or village without people willingly declaring their submission to the religion of Islam.

Secondly, the belief of people in the efficacy of the scholar's prayers attracted many into the fold of Islam. Many of the scholars also learnt and understood the art of healing. So they were and still are consulted by non-Muslims and upon their success in their requests they usually converted to Islam. Abdul-Rahmon explains the circumstance by which Aare Latoosa became a Muslim thus:

The conversion of Latoosa who later became Aare Ona Kakanfo was another rapport between the Mallams and the war leaders. He got converted to Islam through Alfa Bello and his elder brother Ilyas, both migrant scholars from Iseyin. They both migrated to Ibadan where Bello provided spiritual support for Latoosa's quest for a male child on account of which he became a Muslim.

Apart from the non-Muslims, problems of many Muslims were also solved through prayers offered for them by the scholars. Thirdly, many Arabic schools were established by the itinerant scholars. It was on record that between the second half of the 18th century and early 19th century, many centres of Arabic and Islamic education sprang up in the length and breadth of Ibadanland. These included Oke-Gege Centre founded by Shaykh Busari Katibi, Oke-Koto Centre, established by Shaykh AbdulSalam Abubakar Ghatta (Agbotomokekere). Others were Inakoju Madrasah at Oke-Oja, Imām Baasunu Centre, Ita-Okoro and so on.

One of the factors that aided the proliferation of Arabic Centres then was that many warlords in Ibadan wanted their children to learn the Qur'an and advanced Islamic studies to enable them know the "secret" of Mallams' charms and tira. In towns and villages around the metropolis, many Arabic schools also grew up. When an itinerant preacher preached in a town or village without an Arabic school, he would establish one and appoint one of his students to teach there.

Through the activities of the itinerant scholars, a good number of Muslims understood Islam and became committed to it. Many Muslims also had the opportunity of learning more about Islam from the itinerant 
Mallams. This was as a result of inspirational and motivational sermons preached by these scholars which really impacted positively on their lives.

Also, many itinerant scholars had assisted in raising funds for the construction of central mosques in various areas of Ibadanland. Some of their open air services were purposely staged for the launch of the funds for mosque buildings as many of their audience were always carried along and responded generously. That is why mosques are found in nearly all towns and villages in Ibadan less city, though, most of those mosques are now dilapidated for lack of maintenance while others are virtually desolated and this is blamed on the incidence of rural-urban migration. Lastly, the itinerant scholars had used their knowledge to settle conflicts and misunderstanding among Imams and Alfas in many towns and villages in Ibadanland.

\section{Challenges in the Way of Itinerant Scholars}

The itinerant scholars faced series of problems in their chosen career. These include:

\section{Lack of Stable Sources of Income}

Most of them did not engage in income generating ventures. They relied mostly on meager amounts of donations generated at the public programmes. When people consulted them privately for their personal problems, a sort of consultation fee was paid. At that period, Muslim parents gave out their children to Mallams so as to receive Qur'ānic education without paying any fee. In order to keep the bodies and souls of these students together, some scholars resorted to farming, using the students for manual labour.

\section{Attack by Non-Muslims}

Many times, these preachers were attacked by non-Muslims especially the traditionalists, either physically or spiritually. Shaykh Najimudeen shared his experience in this regard. He says:

As a young Muslim preacher among the hard-hearted disbelievers and being armless, I used to run away from them whenever they tried to physically attack me. I continued to endure direct and indirect persecution of the Kuffar until gradually Allah strengthened me spiritually to face them.

\section{Long Distance and Poor Road Network}

Another clog in the wheel of itinerary preaching in the early days of Islam in Ibadan and environs was long distance and poor road network. Some villages are located at far distance while the roads leading to them were in deplorable conditions. Scholars would have to trek long distance before they could reach some villages and at times some of them get discouraged to penetrate deeply into the remote areas.

\section{Poor Attitude of Some Rural Communities to Islamic Preachers}

It was discovered that Islamic preachers were not provided with accommodation in some rural communities. The usual practice was that an Islamic preacher would seek permission from the Imām, Baale or the community leaders before embarking on preaching exercise. But at times, these permissions were turned down just to show their hatred for Islam. Many scholars were not bothered or discouraged about this attitude as they took solace in Allah's word which reads:

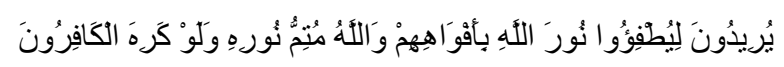

Their intention is to extinguish God's light (by blowing it) with their mouths: but God will complete (the revelation of) His light, even though the unbelievers may detest it. (Q.61:8) 


\section{Itinerary Preaching and Open Public Lecture in the Contemporary Period}

In this modern world, electronic media have virtually taken over the position of itinerary preaching and open public da'wah making these systems becoming outdated and unfashionable. Abbas traced the reason for this development to the complexity of the society and the advancement of electronic technology. He states:

The programme is nowadays very unpopular and has therefore become very uncommon. The reason for this is traceable to the complexity of the society and the advancement of electronic technology which has shifted the focus to the use of electronic media.

Much as one appreciates the immense benefits of electronic media in the propagation of Islam, the lack of it in the rural areas constitutes a great clog in its success particularly at this time when itinerary preaching has outlived its popularity. It means a great loss for the ummāh which statistically forms majority of its dwellers.

However as unpopular as open public lectures may be in cities and towns, it is still useful in villages and hamlets. That is why the National Council of Muslim Youth Organisations (NACOMYO) Oyo state chapter, the Grand Council for Islamic Affairs in Nigeria (GCIAN), the Muslim Students' Society of Nigeria (MSSN) University of Ibadan branch and other associations engage in rural $d a$ ' wah programme by employing the use of open public da'wah system.

\section{Conclusion}

In the foregoing, it is evident that the spread of Islām in Ibadan was at the instance of the itinerant scholars who strove tooth and nail to extend the frontiers of Islām to cover the length and breadth of Ibadanland. Despite the fact that these illustrious ambassadors of Islām neither had sponsors nor received grants from anywhere, yet, the impact of their activities was felt by all and sundry. It is equally explicit from the study that the itinerant scholars faced series of problems in their chosen career. The paper equally submitted that itinerary preaching and open public da'wah are becoming things of the past in the contemporary world since the introduction of electronic media. It is therefore suggested that Muslim communities and individuals should brace up to sponsor programmes on available electronic media for city and town dwellers. As for rural dwellers, physical preaching efforts should be made to satisfy them.

\section{References}

Abbas, L. O. (2003). Imamship in Islam: Its concept and practice among the Yoruba of Oyo and Osun states (Doctor's thesis, Dept. of Arabic and Islamic Studies, University of Ibadan).

Abdul-Rahmon, M. O. (1989). A thematic and stylistic study of Arabic poetry in Ibadan 1876-1976 (Doctor's thesis, Dept. of Arabic and Islamic Studies, University of Ibadan).

Abdul-Rahmon, M. O. (2012). Of "Illiterate" scholars and National development: The Arabic webs in Yoruba loom (An inaugural lecture. University of Ibadan).

Ajimobi, I. A. (2012). State Police in Federal Nigeria: A shoewearer's perspective. Ibadan: office of the governor, Oyo state secretariat, Agodi.

Baasunu, R. A. (2014). The effects of integration of English language and other related subjects into the curriculum of Ma'had Al-Arabi, Elekuro, Ibadan (An M.A. project in the Dept. of Arabic and Islamic studies, University of Ibadan).

Bolaji, S. B. (1970). Asiri Anabi Muhammad. Ilorin: Bolaji Islamic Enterprises.

Central Council of Ibadan Indigenes. (2009). Programme of events for Ibadan week.

Jubril, A. (2015). Footprints of a model clergy. Ibadan: Doubletrust Publication Company.

Lawal, I. B. (1997). The impact of Muslim nursery and primary schools on Ibadan Muslims (A B.A. project in the Dept. of Religions, University of Ilorin). 
Lawal, I. B. (2014). Effect of rural-urban migration on da'wah activities in Ibadan less city (An M.A. project in the Dept. of Arabic Islamic studies, University of Ibadan).

Olanrewaju, B. A. (1995). Shaykh Najimudeen A. Akindele: A portrait of an Islamic scholar (A B.A. long essay, Dept. of Religions, University of Ilorin).

Oral Interview With Alhaj Sirajudeen Oloso (78). Chief Imam of Iwo Road Central Mosque, Ibadan. At his residence, Abayomi area, Ibadan. On Monday 20th July, 2015.

Oral Interview With Alhaj Yusau Lawal (80). Member, Islahudeen Missionary Association, Ibadan branch. At his residence, 11, Idera close, Iwo Road, Ibadan. On Monday 1st June, 2015.

Uthman, I. O. (2007). Al-Jihād al-T'alimi- In search of a united front in educational Jihad and the experience of Yoruba Muslims. Al-Fikr, Annual Journal of the Department of Arabic and Islamic studies, University of Ibadan. 